\title{
Pengelolaan Limbah Kelapa Sawit (Elaeis guineensis Jacq.) di Angsana Estate, Kalimantan Selatan
}

Waste management of palm oil (Elaeis guineensis Jacq.) in Angsana Estate, South Kalimantan

\section{Brury Marco Silalahi dan Supijatno*}

Departemen Agronomi dan Hortikultura, Fakultas Pertanian, Institut Pertanian Bogor (Bogor Agricultural University), Jl. Meranti, Kampus IPB Darmaga, Bogor 16680, Indonesia Telp.\&Faks.62-251-8629353 e-mail agronipb@indo.net.id

*Penulis untuk korespondensi: supijatno@yahoo.co.id

Disetujui 6 November 2017/Published online 14 November 2017

\begin{abstract}
This research was conducted at oil palm plantation of Angsana Estate, South Kalimantan from February until June 2011. The main purpose of this research is to increase knowledge, skill, experience, waste product management of palm oil plantation, and to analyze waste product of palm oil as an organic fertilizer. The analysis result showed that empty fruit bunch (EFB) aplication as organic fertilizer can increase the amount of nutrient on palm oil leaf especially Kalium and palm oil productivity. Palm oil mill effluent (POME) aplication as organic fertilizer can increase total bunch/hectare/year, and increase soil fertility, but not increase the amount of nutrient on palm oil leaf .
\end{abstract}

Keywords : By Products, Oil Palm Plantation, Empty Fruit Bunch (EFB), Palm Oil Mill Effluent (POME)

\begin{abstract}
ABSTRAK
Penelitian ini dilakukan di perkebunan kelapa sawit Angsana Estate, Kalimantan Selatan dari bulan Februari sampai Juni 2011. Tujuan utama penelitian ini adalah untuk meningkatkan pengetahuan, keterampilan, pengalaman pengelolaan produk limbah perkebunan kelapa sawit. Serta untuk menganalisa produk limbah kelapa sawit sebagai pupuk organik. Hasil analisis menunjukkan bahwa pengaplikasian tandan buah kosong (BAPB) sebagai pupuk organik dapat meningkatkan jumlah hara pada daun kelapa sawit khususnya produktivitas Kalium dan minyak kelapa sawit. Aplikasi limbah pabrik kelapa sawit (POME) sebagai pupuk organik dapat meningkatkan jumlah tandan / hektar / tahun, dan meningkatkan kesuburan tanah, namun tidak meningkatkan jumlah hara pada daun kelapa sawit.
\end{abstract}

Kata kunci : limbah pabrik kelapa sawit, perkebunan kelapa sawit, produk, tandan buah kosong 


\section{PENDAHULUAN}

Kelapa sawit (Elaeis guineensis Jacq.) merupakan komoditas perkebunan yang berperan penting bagi perekonomian Indonesia sebagai salah satu penyumbang devisa dari sektor nonmigas. Produk minyak kelapa sawit (MKS) diserap oleh industri pangan terutama minyak goreng dan industri non pangan seperti kosmetik, farmasi, dan lain-lain. Peningkatan permintaan minyak makan dunia khususnya minyak sawit terus terjadi akibat pertambahan penduduk dan peningkatan pendapatan per kapita penduduk dunia (Pahan, 2007).

Peningkatan permintaan minyak sawit dan turunannya harus diimbangi dengan peningkatan produksi kelapa sawit. Usaha untuk meningkatkan produksi kelapa sawit ditempuh dengan perluasan areal perkebunan kelapa sawit dan peningkatan produktivitas. Luas areal perkebunan kelapa sawit di Indonesia pada tahun 2009 mencapai 7.51 juta hektar dengan produksi sebesar 18.64 juta ton minyak sawit dan 3.47 juta ton inti sawit (Pusat Data dan Informasi Pertanian Kementrian Pertanian, 2010).

Peningkatan luas areal dan produktivitas yang cukup tinggi ini diikuti oleh perkembangan industri kelapa sawit. Perkembangan industri kelapa sawit dicirikan dengan pembangunan pabrik kelapa sawit (PKS) terpadu dengan perkebunan yang dapat berdampak positif (melalui penyerapan tenaga kerja dan perbaikan infrastruktur daerah setempat) dan berdampak negatif bagi lingkungan (melalui penurunan kualitas dan kuantitas lingkungan akibat pencemaran serta timbulnya masalah sosial). Oleh karena itu, penerapan konsep zero waste dalam usaha perkebunan sangat dianjurkan.

Limbah kelapa sawit merupakan sisa hasil tanaman kelapa sawit yang tidak termasuk dalam produk utama atau hasil ikutan dari proses pengolahan kelapa sawit. Limbah hasil pengolahan kelapa sawit dibedakan menjadi limbah cair yang biasa dikenal dengan istilah POME (Palm Oil Mill Effluent) serta limbah padat berupa sabut, cangkang, janjangan kosong (JJK) dan solid basah (wet decanter solid) (Pahan, 2007).

Limbah industri kelapa sawit banyak mengandung senyawa organik dan anorganik. Senyawa organik lebih mudah mengalami pemecahan dibandingkan senyawa anorganik. Senyawa organik dapat dirombak oleh bakteri baik secara aerob maupun anaerob. Kesulitan limbah untuk dirombak berpengaruh terhadap kelestarian lingkungan (beban pencemaran). Limbah kelapa sawit mengandung zat beracun seperti logam berat (tembaga, timbal, perak, seng, besi, nikel, dll) yang dapat berpengaruh buruk pada mikroorganisme (Sugiharto, 1987). Di sisi lain kandungan bahan organik yang terkandung dalam limbah hasil pengolahan kelapa sawit merupakan bahan baku potensial yang bernilai ekonomis dan dapat dimanfaatkan untuk meningkatkan produksi tanaman.

Dampak negatif yang mungkin ditimbulkan dari limbah industri kelapa sawit dan pertimbangan potensi bahan organik yang terkandung dalam limbah kelapa sawit yang bisa dimanfaatkan, menuntut perkebunan untuk melakukan kegiatan pengelolaan limbah dengan baik. Aplikasi limbah kelapa sawit sebagai pupuk organik perlu dilakukan dengan benar sehingga biaya yang dikeluarkan tidak terlalu besar dan dapat meminimalisir dampak negatif yang mungkin ditimbulkan demi mewujudkan pertanian yang berkelanjutan serta industri yang ramah lingkungan. Kegiatan magang ini bertujuan untuk mempelajari pengelolaan limbah yang dilakukan perusahaan terutama hal-hal yang berkaitan dengan aplikasi limbah kelapa sawit sebagai pupuk organik.

Tujuan umum kegiatan ini adalah untuk meningkatkan kemampuan profesionalitas penulis sesuai dengan kompetensi penulis agar dapat memahami dan mendalami proses kerja secara nyata serta meningkatkan kemampuan teknis lapangan dan manajerial dalam pengelolaan perkebunan kelapa sawit. Tujuan khususnya adalah untuk mempelajari penanganan dan pemanfaatan limbah kelapa sawit sebagai pupuk organik serta mengetahui dampak aplikasinya terhadap tanaman dan pengaruh aplikasi limbah cair terhadap sifat tanah dan air.

\section{METODE PENELITIAN}

Kegiatan penelitian dilaksanakan di Angsana Estate, Kalimantan Selatan mulai bulan Februari hingga Juni 2011. Kegiatan magang yang dilakukan meliputi kegiatan yang berkaitan dengan aspek teknis di lapangan dan aspek manajerial baik di kebun maupun di kantor kebun, melakukan pengamatan terhadap aspek khusus di lapangan serta kegiatan pengumpulan data. Kegiatan-kegiatan tersebut disesuaikan dengan jadwal dan kebutuhan yang ada di kebun serta disetujui oleh pihak kebun. Pada aspek teknis, penulis diposisikan sebagai karyawan harian lepas (KHL) selama satu bulan yaitu bekerja di lapangan sesuai dengan jenis dan volume pekerjaan yang ada. Pada aspek manajerial, penulis melaksanakan kegiatan sebagai pendamping supervisi (mandor dan kerani) dan 
pendamping asisten divisi. Aspek khusus yang diperdalam pada kegiatan magang ini adalah pengelolaan limbah hasil pengolahan kelapa sawit oleh perusahaan.

Pengumpulan data dilakukan dengan metode langsung (data primer) dan tidak langsung (data sekunder). Pengumpulan data primer dilakukan melalui pengamatan langsung saat mengikuti kegiatan di lapangan sesuai dengan aspek teknis dan aspek khusus yang dipelajari serta diskusi dengan pihak kebun, sedangkan data sekunder diperoleh dari data yang tersedia di kantor kebun. Data yang dikumpulkan meliputi :

1. Kondisi umum kebun (sejarah dan perkembangan, letak geografis kebun, keadaan iklim dan tanah, luas areal dan tata guna lahan, kondisi pertanaman dan produktivitas tanaman lima tahun terakhir, struktur organisasi dan ketenagakerjaan kebun).

2. Data perolehan produksi (Ton/ha/tahun), bobot janjang rata-rata (BJR/tahun), dan jumlah janjang (JJG/ha/tahun) selama lima tahun terakhir untuk blok aplikasi dan blok kontrol.

3. Data hasil analisa status hara dalam daun tanaman kelapa sawit pada blok aplikasi dan blok kontrol.

4. Kualitas limbah cair (kandungan BOD, COD, TSS, pH, amoniak, kandungan minyak dan lemak, nitrogen total, dan logam berat).

5. Data analisis tanah; sifat fisik tanah (tekstur, bobot per volume, porositas dan permeabilitas) dan kimia tanah ( $\mathrm{pH}, \mathrm{C}$-organik, nitrogen, $\mathrm{Na}, \mathrm{K}, \mathrm{Ca}, \mathrm{Mg}, \mathrm{P}_{2} \mathrm{O}_{5}, \mathrm{KTK}$, kejenuhan aluminium, dan logam-logam berat).

6. Data produksi dan aplikasi limbah padat (JJK) dan limbah cair (effluent) selama satu bulan.

Data hasil analisis status hara dalam daun kelapa sawit dan perolehan produksi tanaman kelapa sawit antara lahan aplikasi dan kontrol dianalisis dengan uji statistik Independent t-test (Uji t-student). Jumlah blok untuk variabel yang dibandingkan masing-masing sebanyak 3 blok. Jumlah blok sebagai ulangan. Variabel pengamatan lainnya dianalisis secara deskriptif.

\section{HASIL DAN PEMBAHASAN}

\section{Kondisi Umum}

Angsana Estate terletak di desa Bayansari, kecamatan Angsana, kabupaten Tanah Bumbu, provinsi Kalimantan Selatan. Secara Geografis ASE berada pada (115 $\left.33^{\prime} 34^{\prime \prime}\right)$ (115 $\left.39^{\circ} 46^{\prime \prime}\right)$ BT dan $\left(-3^{0} 38^{\prime} 45^{\prime \prime}\right)-\left(-3^{0} 35^{\prime} 39^{\prime \prime}\right)$ LS. Angsana Estate memilki luas total berdasarkan HGU sebesar 3249.99 ha dengan rincian: 3047.56 ha plant area/ditanami kelapa sawit (TM dan TBM), areal pabrik (ASF) seluas 34.51 ha, areal prasarana seluas 121.59 ha, serta sungai, bukit, dan lembah seluas 46.33 ha. ASE terbagi menjadi tiga divisi dengan luas masingmasing: divisi I seluas 1254.55 ha, divisi II seluas 859.19 ha, dan divisi III seluas 1136.25 ha.

Angsana Estate terletak pada ketinggian 15 meter dari permukaan laut dengan suhu ratarata berkisar antara $28-32^{\circ} \mathrm{C}$, temperatur udara terendah terjadi pada bulan Juli dan tertinggi pada bulan Desember, dengan fluktuasi temperatur rata-rata bulanan relatif kecil yakni $9.2^{\circ} \mathrm{C}$. Kelembaban udara termasuk dalam kategori sedang dengan kisaran antara $76 \%$ sampai dengan $85 \%$ dengan lama penyinaran matahari rata-rata bulanan berkisar antara $34 \%$ sampai dengan $62 \%$. Berdasarkan data curah hujan dan hari hujan sepuluh tahun terakhir (2001-2009), ASE memiliki rata-rata curah hujan tahunan sebesar 2 $664 \mathrm{~mm} /$ tahun dengan hari hujan rata-rata 131 hari/tahun. Berdasarkan klasifikasi iklim menurut Schmidt \& Ferguson, tipe iklim di ASE termasuk dalam tipe iklim B (daerah basah dengan vegetasi hutan hujan tropis) dengan nilai Q sebesar 23.90 $\%$. Distribusi curah hujan di ASE tidak merata sepanjang tahun. Rata-rata curah hujan terendah terjadi selama 4 bulan berturut-turut (Agustus Nopember).

Berdasarkan hasil survei tanah semi detil pada tahun 2006 yang dilakukan oleh Departemen Riset Minamas diketahui bahwa sebagian besar tanah di ASE didominasi oleh jenis tanah Oxisol. Oxisol merupakan jenis tanah tua yang mengalami pelapukan lanjut dan terbentuk pada daerah dengan topografi berombak sampai berbukit, yang dicirikan oleh kandungan basa-basa $(\mathrm{N}, \mathrm{P}, \mathrm{K}, \mathrm{Ca}$, $\mathrm{Mg}$, dan $\mathrm{Na}$ ) rendah karena pencucian yang intensif, KTK efektif yang rendah, dan $\mathrm{pH}$ tanah yang cenderung masam.

\section{Produksi, Karakteristik dan Pengelolaan Limbah Kelapa Sawit}

Pengolahan TBS (tandan buah segar) di PKS akan menghasilkan produk utama (CPO dan kernel) serta hasil sampingan (by-products) dalam bentuk limbah padat berupa janjang kosong (JJK), cangkang, dan sabut serta limbah cair (POME). Jumlah limbah yang dihasilkan oleh pabrik kelapa sawit (PKS) bergantung pada kapasitas olah pabrik, rencana jam olah, sistem pengolahan dan keadaan peralatannya (efisiensi alat). Pabrik kelapa sawit (PKS) yang beroperasi di PT LSI memiliki kapasitas 60 ton TBS/jam dengan rencana jam olah pabrik 20 jam per hari. 
Berdasarkan pengamatan pada bulan April 2011, rata-rata total TBS yang diolah oleh ASF mencapai 887.523 ton per hari dan menghasilkan produksi berupa CPO sebesar 200.326 ton/hari atau sekitar $22.6 \%$ dari TBS diolah, janjangan kosong sebesar 182.36 ton/hari atau sekitar $20.57 \%$ dari TBS diolah, dan limbah cair (POME) sebesar $571 \mathrm{~m}^{3} /$ hari atau sekitar $64.35 \%$ dari TBS diolah.

Pengelolaan hasil samping (by product) dilakukan berlandaskan pada komitmen untuk menjaga kelestarian lingkungan. Cangkang dan serabut (fiber) dimanfaatkan kembali untuk bahan bakar boiler di PKS, janjangan kosong (JJK) dan limbah cair (POME) diaplikasikan sebagai pupuk organik ke lapangan dengan metode aplikasi dan dosis yang tepat sesuai dengan rekomendasi Departemen Riset.

Aplikasi Janjangan kosong. Janjangan kosong (JJK) adalah sisa buah tandan kelapa sawit yang berasal dari stasiun bantingan (thresher) di PKS. Produksi JJK sekitar 20-23 \% dari tiap ton TBS yang diolah. JJK yang diproduksi di pabrik, ditampung sementara di hopper untuk kemudian diaplikasikan ke lapangan. JJK diangkut dari PKS ke blok aplikasi dengan menggunakan truk pengangkut TBS (jenis PS kapasitas 6 ton, jenis HINO kapasitas 8 ton).

JJK dari PKS ditumpuk di collection road kemudian diaplikasikan ke setiap titik secara manual dengan menggunakan kereta sorong (angkong). Aplikasi pada TBM diberikan di piringan dan untuk TM di gawangan mati (antara pohon) masing-masing satu lapis. Metode aplikasi JJK di ASE terdiri dari aplikasi dengan teknik mulching dengan dosis $275 \mathrm{~kg} / \mathrm{titik}$ (37.5 ton/ha) dan focal feeding di gawangan mati dengan dosis 2 ton/lubang. Ukuran lubang untuk focal feeding adalah panjang 4 meter, lebar 1 meter, dan dalamnya 0.75 meter. Aplikasi JJK dilakukan dengan rotasi 1 kali per tahun.

Dari total JJK yang dihasilkan ASF, hanya $45 \%$ saja yang diaplikasikan ke ASE, sisanya dikirim ke kebun-kebun tetangga (GSE, PBE, dan MTE). Berdasarkan perkiraan produksi total JJK sebesar 54708.576 ton/tahun (dihitung dari produksi JJK bulan April 2011 sebesar 4 559.048 ton), maka jumlah JJK yang diterima ASE sebesar 24618.859 ton/tahun sehingga total luas lahan yang dapat diaplikasi JJK adalah sebesar 656.502 ha/tahun (dosis 37.5 ton/ha dengan rotasi satu kali setahun) atau hanya sekitar 1/6 dari total luas plant area ASE (3047.56 ha).

Organisasi pekerjaan aplikasi JJK diatur se-efisien mungkin, karena biayanya cukup mahal. Prestasi kerja aplikasi JJK di lapangan sekitar $5 \mathrm{HK} / \mathrm{ha} /$ rotasi (dosis aplikasi 37.5 ton
JJK/ha atau $275 \mathrm{~kg} \mathrm{JJK} /$ titik) dengan kisaran upah per HK Rp 48600.00 (per titik Rp 1 800.00) sehingga biaya tenaga kerja aplikasi per hektar untuk satu kali rotasi sebesar Rp 243 000.00.

Aplikasi Limbah Cair. Limbah cair yang dihasilkan pabrik merupakan produk sampingan dari pengolahan TBS di PKS yang berasal dari proses perebusan (sterilizer), pemurnian (clarifier), air cucian pabrik, dan air hydrocyclon (air buangan dari proses pemisahan cangkang dan inti sawit). Sebelum diaplikasikan ke lahan, limbah cair diolah terlebih dahulu di stasiun Instalasi Pembuangan Air Limbah (IPAL) dan melalui beberapa perlakuan sehingga memenuhi standar mutu (BOD yang sesuai) untuk diaplikasikan. Kolam yang terpasang pada stasiun IPAL di ASF terdiri dari 8 kolam. Kapasitas tiap kolam dihitung $60 \%$ dari ukuran total kolam, yang berarti kolam tidak terisi penuh (hanya terisi $60 \%$ ). Masa retensi berkisar antara 89-147 hari.

Tabel 1. Spesifikasi kolam limbah di IPAL ASF

\begin{tabular}{ccccc}
\hline No & Kolam & $\begin{array}{c}\text { Ukuran } \\
(\text { pxlxt }) \\
(\mathrm{m})\end{array}$ & $\begin{array}{c}\text { Kapasitas } \\
\left(\mathrm{m}^{3}\right)\end{array}$ & $\begin{array}{c}\text { Masa } \\
\text { Retensi } \\
(\text { hari })\end{array}$ \\
\hline 1 & Cooling & $48 \times 15 \times 5$ & 2160 & $4-6$ \\
2 & $\begin{array}{c}\text { Mixing Pound } \\
\text { Anaerobik } \\
\text { Pound }\end{array}$ & $80 \times 20 \times 5$ & 4800 & $6-10$ \\
3 & $\begin{array}{c}\text { Anaerobik } \\
\text { Pound }\end{array}$ & $100 \times 20 \times 7$ & 8400 & $6-10$ \\
4 & $\begin{array}{c}\text { Anaerobik } \\
\text { Pound }\end{array}$ & $120 \times 30 \times 7$ & 12600 & $9-15$ \\
5 & $\begin{array}{c}\text { Anaerobik } \\
\text { Pound }\end{array}$ & $120 \times 30 \times 5$ & 10800 & $14-24$ \\
7 & $\begin{array}{c}\text { Aerobik } \\
\text { Pound }\end{array}$ & $50 \times 90 \times 7$ & 18900 & $23-38$ \\
8 & $\begin{array}{c}\text { Aplication } \\
\text { Pound }\end{array}$ & $100 \times 30 \times$ & 9900 & $13-21$ \\
\hline Su & 5.5 & & $14-23$ \\
\hline
\end{tabular}

Sumber: Angsana Factory, (2011)

Sistem aplikasi lahan yang digunakan adalah sistem kolam datar (flat bed) yaitu sistem irigasi yang ditampung pada kolam-kolam datar (seperti rorak-rorak) secara berhubungan dengan ketinggian yang relatif tidak sama atau seperti bentuk terasering. Flat bed dibuat pada gawangan mati, berbentuk empat persegi panjang dengan ukuran panjang $3.2 \mathrm{~m}$, lebar $1.4 \mathrm{~m}$ dan kedalaman efektif $0.4 \mathrm{~m}$ dengan kapasitas $1.792 \mathrm{~m}^{3}$ air limbah. Jumlah flat bed per hektar adalah 140160 flat bed.

Aplikasi effluent dilakukan dengan dosis $7.5 \mathrm{~cm}$ rey $($ rey $=$ rain equivalent per year $/$ setara curah hujan per tahun) atau setara dengan 750 ton/ha/tahun. Aplikasi dilakukan dengan rotasi 3 (tiga) kali setahun sehingga dosis tiap aplikasinya sebesar 250 ton/ha. Limbah cair yang akan diaplikasikan dipompakan melalui pipa-pipa 
kemudian dialirkan ke flat bed. Effluent mengalir antar flat bed secara grafitasi.

Berdasarkan produksi pada bulan april 2011, perkiraan total limbah cair yang dihasilkan sebesar 171336 ton/tahun sehingga luas total areal yang dapat diaplikasi sebesar 228.45 ha per tahun (dosis 750 ton/ha/tahun). Saat ini luas lahan apliksi di PT LSI telah mencapai 292 ha dengan jumlah flat bed yang tersedia sebanyak 42130 buah.

\section{Dampak Aplikasi Limbah terhadap Tanaman}

Analisis dampak aplikasi limbah terhadap tanaman dilakukan dengan membandingkan status hara pada daun dan produksi tanaman antara lahan yang mendapat aplikasi limbah dengan lahan yang tidak mendapat aplikasi (kontrol). Blok untuk aplikasi limbah padat (JJK) adalah blok C24, C25, C26 dengan blok kontrolnya blok C15, C16, C17 (parameter yang dibandingkan antara lain adalah unsur $\mathrm{N}, \mathrm{P}, \mathrm{K}, \mathrm{Mg}$, dan $\mathrm{Ca}$ yang masing-masing dinyatakan dalam $\%$ on dry matter). Blok untuk aplikasi limbah cair adalah blok B19, B20, B21 dan blok kontrolnya blok D36, D37, D38 (parameter produksi yang dibandingkan yaitu produktivitas tanaman (Ton/ha/tahun), jumlah janjang (JJG/ha/tahun), dan bobot janjang ratarata (BJR/tahun)).

1. Dampak Aplikasi terhadap Status Hara pada Daun

Berdasarkan hasil analisa sampel daun tanaman kelapa sawit terlihat bahwa status hara dalam daun antara lahan aplikasi janjangan kosong (JJK) dan lahan kontrol tidak berbeda nyata kecuali unsur $\mathrm{K}$ (Tabel 2). Hal ini terjadi karena JJK belum diaplikasikan secara maksimal (full blok). Aplikasi yang tidak maksimal ini disebabkan karena kontur lahan yang tidak datar dan sarana dalam blok yang kurang memadai (seperti titi panen dan pasar rintis) sehingga menyulitkan aplikasi yang dilakukan secara manual.

Hanya unsur Kalium (K) yang menunjukkan hasil yang berbeda nyata antara blok aplikasi dengan blok kontrol. Hal ini disebabkan karena unsur K merupakan unsur yang persentasenya paling tinggi dalam setiap ton JJK dibandingkan dengan unsur lainnya (Pahan, 2007). Selain itu, unsur K merupakan unsur yang paling banyak di temukan di dalam tanah dan diserap oleh tanaman dalam jumlah yang lebih banyak dari yang dibutuhkan (Hardjowigeno, 2003), sehingga ketersediaan unsur hara $K$ pada daun tanaman kelapa sawit di lahan aplikasi lebih tinggi dibandingkan unsur hara lainnya.
Tabel 2. Hasil analisa daun pada blok aplikasi JJK dan blok kontrol

\begin{tabular}{ccc}
\hline $\begin{array}{c}\text { Kandungan Hara dalam } \\
\text { Daun } \\
\text { (\% On Dry Matter) }\end{array}$ & $\begin{array}{c}\text { Lahan Aplikasi Lahan Kontrol } \\
\text { (LA) }\end{array}$ \\
\hline $\mathrm{N}$ & $2.7233 \mathrm{a}$ & $2.9400 \mathrm{a}$ \\
$\mathrm{P}$ & $0.1683 \mathrm{a}$ & $0.1760 \mathrm{a}$ \\
$\mathrm{K}$ & $1.1633 \mathrm{a}$ & $0.9873 \mathrm{~b}$ \\
$\mathrm{Mg}$ & $0.2357 \mathrm{a}$ & $0.2457 \mathrm{a}$ \\
$\mathrm{Ca}$ & $0.5420 \mathrm{a}$ & $0.5860 \mathrm{a}$ \\
\hline
\end{tabular}

Keterangan : angka pada baris yang sama dan diikuti huruf yang sama menunjukkan hasil tidak berbeda nyata berdasarkan uji $t$-student pada taraf nyata $5 \%$

Berdasarkan hasil analisa sampel daun tanaman kelapa sawit terlihat bahwa status hara dalam daun pada blok aplikasi limbah cair (effluent) memiliki status hara yang tidak berbeda nyata dengan blok kontrol (Tabel 3). Hal ini terjadi karena limbah cair yang diaplikasikan memiliki nilai BOD yang rendah $(<1000 \mathrm{mg} / \mathrm{l})$ sehingga kandungan hara dalam limbah cair yang diaplikasikan juga rendah. Nilai BOD yang rendah disebabkan oleh penurunan konsentrasi limbah akibat bercampur dengan air hujan dan air cucian pabrik selama pengolahan limbah di stasiun limbah (IPAL) pabrik. Perusahaan juga telah mengatur sedemikian rupa agar BOD limbah sebelum dialirkan berada di bawah $1000 \mathrm{mg} / \mathrm{l}$ dengan tujuan untuk meminimalisir beban pencemaran jika terjadi rembesan dan atau limpahan air limbah dari kolam limbah maupun flat bed.

Tabel 3. Hasil analisis daun pada blok aplikasi limbah cair dan blok kontrol

\begin{tabular}{ccc}
\hline $\begin{array}{c}\text { Kandungan Hara dalam } \\
\text { Daun } \\
\text { (\% On Dry Matter) }\end{array}$ & $\begin{array}{c}\text { Lahan } \\
\text { Aplikasi } \\
\text { (LA) }\end{array}$ & $\begin{array}{c}\text { Lahan } \\
\text { Kontrol } \\
(\text { LK) }\end{array}$ \\
\hline $\mathrm{N}$ & $2.9267 \mathrm{a}$ & $2.6933 \mathrm{a}$ \\
$\mathrm{P}$ & $0.1810 \mathrm{a}$ & $0.1700 \mathrm{a}$ \\
$\mathrm{K}$ & $1.0843 \mathrm{a}$ & $1.0430 \mathrm{a}$ \\
$\mathrm{Mg}$ & $0.2807 \mathrm{a}$ & $0.2700 \mathrm{a}$ \\
$\mathrm{Ca}$ & $0.5337 \mathrm{a}$ & $0.6253 \mathrm{a}$ \\
\hline Keterangan : angka pada baris yang sama dan diikuti huruf \\
yang sama menunjukkan hasil tidak berbeda \\
nyata berdasarkan uji $t$-student pada taraf nyata \\
5\%
\end{tabular}

2. Dampak Aplikasi terhadap Perolehan Produksi Aplikasi JJK dapat meningkatkan produktivitas tanaman kelapa sawit tetapi belum konsisten karena perolehan produksi (ton/ha/tahun dan JJG/ha/tahun) di lahan aplikasi pada tahun 2007/2008 berbeda nyata lebih rendah dibandingkan di lahan kontrol (Tabel 4). Hal ini dapat disebabkan karena aplikasi JJK belum diaplikasikan secara maksimal (full blok). 
Aplikasi yang tidak maksimal ini disebabkan karena kontur lahan yang tidak datar dan sarana dalam blok yang kurang memadai (seperti titi panen dan pasar rintis) sehingga menyulitkan aplikasi yang dilakukan secara manual.

Tabel 4. Perbandingan produksi antara lahan aplikasi JJK 9LA) dengan lahan kontrol (LK)

\begin{tabular}{ccrr}
\hline Parameter & Tahun & $\begin{array}{c}\text { Lahan } \\
\text { Aplikasi } \\
\text { (LA) }\end{array}$ & $\begin{array}{c}\text { Lahan } \\
\text { Kontrol } \\
\text { (LK) }\end{array}$ \\
\hline \multirow{5}{*}{ Ton/ha/thn } & $2004 / 2005$ & $17.01 \mathrm{a}$ & $14.04 \mathrm{~b}$ \\
& $2005 / 2006$ & $26.09 \mathrm{a}$ & $24.91 \mathrm{a}$ \\
& $2006 / 2007$ & $17.34 \mathrm{a}$ & $14.04 \mathrm{~b}$ \\
& $2007 / 2008^{*}$ & $17.25 \mathrm{a}$ & $22.17 \mathrm{~b}$ \\
& $2008 / 2009$ & $15.42 \mathrm{a}$ & $17.02 \mathrm{a}$ \\
\hline \multirow{3}{*}{ JJG/ha/thn } & $2004 / 2005$ & $1344 \mathrm{a}$ & $1292 \mathrm{a}$ \\
& $2006 / 2006$ & $2011 \mathrm{a}$ & $1830 \mathrm{a}$ \\
& $2007 / 2008^{*}$ & $1239 \mathrm{a}$ & $981 \mathrm{~b}$ \\
& $2008 / 2009$ & $725 \mathrm{a}$ & $1386 \mathrm{~b}$ \\
& $2004 / 2005$ & $12.66 \mathrm{a}$ & $10.94 \mathrm{~b}$ \\
\hline \multirow{3}{*}{ BJR/thn } & $2005 / 2006$ & $12.99 \mathrm{a}$ & $13.62 \mathrm{a}$ \\
& $2006 / 2007$ & $14.01 \mathrm{a}$ & $14.31 \mathrm{a}$ \\
& $2007 / 2008$ & $15.04 \mathrm{a}$ & $16.00 \mathrm{a}$ \\
& $2008 / 2009$ & $21.27 \mathrm{a}$ & $19.82 \mathrm{a}$ \\
\hline
\end{tabular}

Keterangan : angka pada baris yang sama dan diikuti huruf yang sama menunjukkan hasil tidak berbeda nyata berdasarkan uji $t$-student pada taraf nyata $5 \%$

Tabel 5. Perbandingan produksi antara lahan aplikasi limbah cair (LA) dengan lahan kontrol (LK)

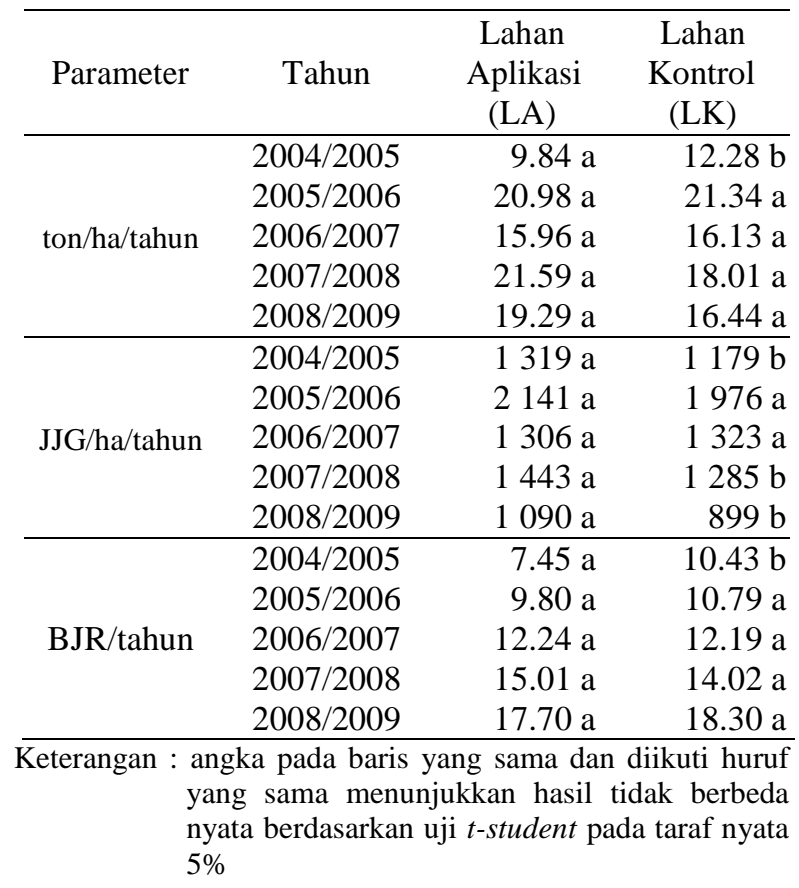

Aplikasi limbah cair ke lahan aplikasi memberikan dampak positif terhadap produksi terutama terhadap peningkatan perolehan jumlah JJG/ha/tahun. Pada tahun 2007/2008 dan 2008/2009 terlihat perolehan jumlah JJG/ha/tahun di lahan aplikasi berbeda nyata lebih tinggi dibandingkan dengan lahan kontrol. Aplikasi limbah cair menambah ketersedian air di lapangan. Ketersediaan air sangat berpengaruh terhadap nisbah bunga jantan dan bunga betina. Stress air (kekeringan) mengakibatkan jaringan tanaman tidak dapat mempertahankan jumlah air dalam sel dan tekanan turgor sel menurun, penyerapan unsur hara dari dalam tanah menurun, proses-proses fisiologis dan distribusi asimilat terganggu serta neto fotosintesis menurun, akibatnya tanaman akan cenderung memproduksi bunga jantan lebih banyak sehingga produksinya menurun (Darmosarkoro, 2001). Penambahan limbah cair ke lahan aplikasi dapat meningkatkan persentase bunga betina sehingga perolehan jumlah JJG/ha/tahun lebih tinggi dibandingkan dengan lahan kontrol.

\section{Dampak Aplikasi Limbah Cair terhadap Sifat Tanah}

Pengkajian dampak aplikasi limbah cair ke lahan perkebunan kelapa sawit terhadap sifatsifat tanah (fisik dan kimia tanah) di PT LSI dilakukan setiap tahun. Pada tahun 2010 dilakukan analisa laboratorium terhadap sifat fisik dan kimia tanah pada sampel tanah yang diambil dari lahan pengkajian dengan parameter yang disesuaikan dengan peraturan pemerintah. Pengambilan sampel tanah dilakukan pada tiga lokasi yaitu di lahan kontrol, lahan aplikasi (satu meter dari pinggir flat bed), dan dalam flat bed.

\section{Sifat Fisik Tanah}

Penentuan sifat fisik tanah dilakukan dengan mengambil sampel tanah utuh untuk menentukan kelas tekstur tanah, menghitung bobot per volume (B/V), porositas \& permeabilitas tanah. Sampel tanah untuk menentukan tekstur tanah diambil pada kedalaman 0-20 cm, 20-40 cm, 40-60 cm, 60-80 $\mathrm{cm}, 80-100 \mathrm{~cm}$, dan 100-120 cm. Sampel tanah untuk menentukan bobot per volume $(\mathrm{B} / \mathrm{V})$, porositas, \& permeabilitas tanah diambil pada kedalaman 0-30 cm dan 30-60 cm.

Tekstur tanah. Tekstur tanah menunjukkan kasar halusnya tanah yang dinyatakan dalam perbandingan proporsi (\%) antara komposisi partikel-partikel penyusun tanah, yaitu perbandingan antara fraksi tanah halus/liat $(<2 \mu \mathrm{m})$, fraksi sedang/debu $(2-50 \mu \mathrm{m})$ serta fraksi kasar/pasir $(50 \mu-2 \mathrm{~mm})$ (Hardjowigeno, 2003). 
Tabel 6. Tekstur tanah pada lahan kontrol (LK), lahan aplikasi (LA), dan dalam flat bed (DF)

\begin{tabular}{|c|c|c|c|c|c|c|c|}
\hline & \multirow{2}{*}{ Tekstur } & \multicolumn{6}{|c|}{ Kedalaman $(\mathrm{cm})$} \\
\hline & & $0-20$ & $20-40$ & $40-60$ & $60-80$ & $80-100$ & $100-120$ \\
\hline \multirow{4}{*}{ LK } & Pasir & 39.71 & 39.92 & 30.29 & 28.98 & 23.74 & 27.52 \\
\hline & Debu & 29.49 & 27.17 & 26.96 & 26.09 & 24.19 & 24.92 \\
\hline & Liat & 30.8 & 32.91 & 42.75 & 44.93 & 52.07 & 47.56 \\
\hline & Kelas & $\begin{array}{c}\text { Lempung } \\
\text { berliat }\end{array}$ & $\begin{array}{c}\text { Lempung } \\
\text { berliat }\end{array}$ & $\begin{array}{l}\text { Berliat } \\
\text { (halus) }\end{array}$ & $\begin{array}{l}\text { Berliat } \\
\text { (halus) }\end{array}$ & $\begin{array}{l}\text { Berliat } \\
\text { (halus) }\end{array}$ & $\begin{array}{l}\text { Berliat } \\
\text { (halus) }\end{array}$ \\
\hline \multirow{4}{*}{ LA } & Pasir & 31.28 & 43.62 & 32.01 & 29.38 & 38 & 48.12 \\
\hline & Debu & 38.88 & 11.9 & 30.39 & 27.32 & 21.32 & 15.86 \\
\hline & Liat & 29.84 & 44.48 & 42.6 & 43.3 & 40.68 & 36.02 \\
\hline & Kelas & $\begin{array}{c}\text { Lempung } \\
\text { berliat }\end{array}$ & $\begin{array}{l}\text { Berliat } \\
\text { (halus) }\end{array}$ & $\begin{array}{l}\text { Berliat } \\
\text { (halus) }\end{array}$ & $\begin{array}{l}\text { Berliat } \\
\text { (halus) }\end{array}$ & $\begin{array}{l}\text { Berliat } \\
\text { (halus) }\end{array}$ & $\begin{array}{c}\text { Liat } \\
\text { berpasir }\end{array}$ \\
\hline \multirow{4}{*}{ DF } & Pasir & 27.11 & 25.44 & 23.13 & 27.36 & 20.99 & 43.11 \\
\hline & Debu & 32.61 & 25.64 & 25.4 & 23.93 & 28.37 & 17.15 \\
\hline & Liat & 40.28 & 48.92 & 51.48 & 48.71 & 50.64 & 39.74 \\
\hline & Kelas & $\begin{array}{l}\text { Berliat } \\
\text { (halus) }\end{array}$ & $\begin{array}{l}\text { Berliat } \\
\text { (halus) }\end{array}$ & $\begin{array}{l}\text { Berliat } \\
\text { (halus) }\end{array}$ & $\begin{array}{l}\text { Berliat } \\
\text { (halus) }\end{array}$ & $\begin{array}{l}\text { Berliat } \\
\text { (halus) }\end{array}$ & $\begin{array}{l}\text { Berliat } \\
\text { (halus) }\end{array}$ \\
\hline
\end{tabular}

Sumber : Kantor Besar ASE (2011); Hasil analisa tanah di Lab. PPLH Lembaga Penelitian Universitas Lambung Mangkurat, Sepetember 2010

Berdasarkan perbandingan fraksi tanah (pasir, debu, dan liat) pada lahan kontrol, lahan aplikasi, dan dalam flat bed, tekstur tanah di ketiga lokasi tersebut tergolong dalam kelas tekstur lempung berliat, berliat (halus), dan liat berpasir. Aplikasi limbah cair dapat memperbaiki tekstur tanah terutama pada tanah bagian permukaan. Hal ini terlihat dari tekstur tanah di lahan aplikasi dan dalam flat bed pada kedalaman 0-20 cm dan 20-40 cm termasuk kelas berliat (halus) sedangkan di lahan kontrol pada kedalaman yang sama termasuk dalam kelas lempung berliat. Hal ini disebabkan karena adanya penambahan bahan organik dari aplikasi limbah cair. Perbandingan antara partikel penyusun tanah pada lahan kontrol, lahan aplikasi, dan dalam flat bed relatif sama (Tabel 6).

Bobot per volume $(\mathrm{B} / \mathrm{V})$, porositas, dan permeabilitas. Bobot per volume $(\mathrm{B} / \mathrm{V})$ tanah merupakan kerapatan tanah per satuan volume yang menunjukkan perbandingan antara berat tanah kering dengan volume tanah termasuk pori tanah. Porositas tanah adalah proporsi ruang pori total yang terdapat dalam satuan volume tanah yang dapat ditempati oleh udara dan air (bagian yang tidak terisi padatan tanah). Permeabilitas tanah menunjukkan kemampuan tanah untuk ditembus oleh air gravitasi dalam kondisi jenuh secara vertikal. Permebilitas tanah dikelompokkan menjadi: sangat lambat $(<0.5 \mathrm{~cm} / \mathrm{jam})$, agak lambat $\quad(0.5-2.0 \quad \mathrm{~cm} / \mathrm{jam}), \quad$ sedang $\quad(2.0-6.25$ $\mathrm{cm} / \mathrm{jam})$, agak cepat $(6.25-12.5 \mathrm{~cm} / \mathrm{jam})$, dan cepat $(>12.5 \quad \mathrm{~cm} / \mathrm{jam})$ (Hardjowigeno \& Widiatmaka, 2001).

Nilai B/V tanah pada lahan aplikasi dan dalam flat bed lebih tinggi dibandingkan pada lahan kontrol (Tabel 7). Hal ini menunjukkan bahwa penambahan bahan organik dari aplikasi limbah cair meningkatkan bobot per volume tanah, yang berarti kemampuan tanah untuk menahan air dan unsur hara menjadi lebih baik. Air limbah yang diaplikasikan mengisi ruang pori tanah terutama pori makro sehingga porositas tanah di lahan kontrol cenderung lebih tinggi daripada di lahan aplikasi dan dalam flat bed. Permeabilitas tanah di lahan aplikasi, kontrol, dan flat bed tergolong sedang tetapi permeabilitas tanah di dalam flat bed lebih rendah dibandingkan pada lahan kontrol dan lahan aplikasi. Hal ini menunjukkan bahwa kondisi tanah di dalam flat bed sudah jenuh air akibat penambahan limbah cair.

Tabel 7. Bobot per volum (B/V), porositas, dan permeabilitas tanah di lahan kontrol (LK), lahan aplikasi (LA), dan dalam flat bed (DF)

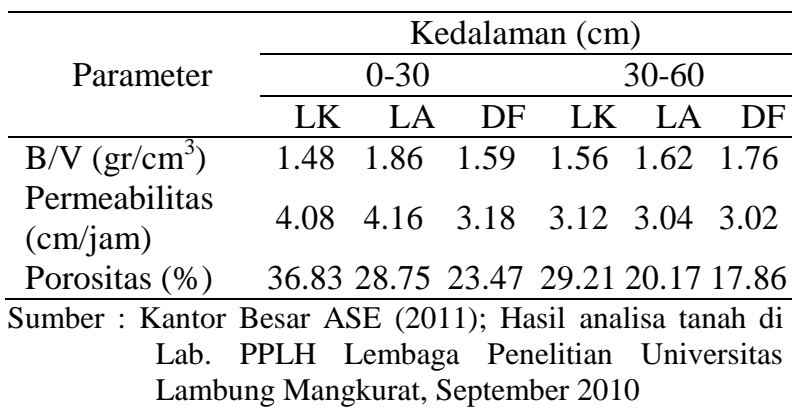

\section{Sifat Kimia Tanah}

Sampel tanah untuk menentukan sifat kimia tanah diambil pada kedalaman 0-20 cm, 20$40 \mathrm{~cm}, 40-60 \mathrm{~cm}, 60-80 \mathrm{~cm}, 80-100 \mathrm{~cm}$, dan 100$120 \mathrm{~cm}$. Pengambilan sampel tanah dilakukan pada tiga lokasi yaitu di lahan kontrol, lahan aplikasi (satu meter dari pinggir flat bed), dan 
dalam flat bed (Tabel 8).

Reaksi tanah (pH tanah). Reaksi tanah menunjukkan sifat kemasaman atau alkalinitas tanah yang dinyatakan dengan nilai $\mathrm{pH}$. Nilai $\mathrm{pH}$ penting sebagai indikasi ketersediaan dan penyerapan unsur hara oleh tanaman (mudah tidaknya unsur hara diserap oleh tanaman), menunjukkan adanya unsur-unsur yang dapat bersifat racun, serta mempengaruhi perkembangan organisme tanah. Pada Tabel 8 terlihat bahwa nilai pH pada lahan kontrol, lahan aplikasi dan dalam flat bed relatif sama yaitu pada kisaran sangat masam $(\mathrm{pH}<4.5)$ sampai agak masam $(\mathrm{pH}$ 5.66.5) tetapi $\mathrm{pH}$ tanah pada kedalaman $0-20 \mathrm{~cm}$ di dalam flat bed mendekati netral. Pada tanah masam unsur P tidak dapat diserap oleh tanaman karena diikat (difiksasi) oleh Al. Selain itu ion-ion $\mathrm{Al}$ dalam jumlah banyak dapat menjadi racun.

Kandungan C-Organik, Nitrogen, dan Fospor. Kandungan C-organik dan nitrogen $(\mathrm{N})$ pada lahan kontrol, lahan aplikasi dan dalam flat bed di setiap kedalaman menunjukkan nilai yang relatif sama yaitu pada kisaran sedang-tinggi kecuali kandungan C-organik di lahan aplikasi dan dalam flat bed pada kedalaman 0-20 cm yang termasuk sangat tinggi. Hal ini menunjukkan bahwa aplikasi limbah cair menambah ketersediaan kandungan bahan organik (C organik dan nitrogen) pada tanah bagian permukaan. Kandungan $\mathrm{P}_{2} \mathrm{O}_{5}$ (bray) paling tinggi terlihat pada kedalaman $0-20 \mathrm{~cm}$ dan $20-40 \mathrm{~cm}$ di dalam flat bed. Unsur $\mathrm{P}$ tersedia dan mudah diserap oleh tanaman pada kondisi $\mathrm{pH}$ netral $(\mathrm{pH}$ 6.6-7.5) sedangkan pada kondisi masam (seperti pada lahan kontrol dan lahan aplikasi) unsur P difiksasi oleh Al sehingga jumlahnya sedikit.

Kation-kation basa dapat tukar dan kejenuhan aluminium (Al-dd). Aplikasi limbah cair ke lahan perkebunan memberikan pengaruh positif dalam meningkatkan kesuburan tanah, terlihat dari peningkatan kandungan konsentrasi kation-kation basa dapat tukar dalam tanah. Jumlah kation-kation basa berhubungan erat dengan $\mathrm{pH}$ tanah, dimana tanah dengan $\mathrm{pH}$ rendah umumnya mempunyai jumlah kation-kation basa rendah dan sebaliknya tanah dengan $\mathrm{pH}$ tinggi mempunyai jumlah kation-kation basa tinggi (Hardjowigeno, 2003). Pada Tabel 8 terlihat bahwa kandungan unsur $\mathrm{Mg}, \mathrm{Na}$, dan $\mathrm{K}$ pada lahan aplikasi dan dalam flat bed lebih baik dibandingkan lahan kontrol sedangkan kandungan $\mathrm{Ca}$ relatif sama hampir setiap kedalaman. Kejenuhan aluminium (Al-dd) relatif sama antara lahan aplikasi, lahan kontrol, dan dalam flat bed.

Tabel 8. Sifat kimia tanah pada berbagai kedalaman di lahan kontrol (LK), lahan aplikasi (LA), dan dalam flat bed (DF)

\begin{tabular}{|c|c|c|c|c|c|c|c|c|c|c|}
\hline $\begin{array}{c}\text { Kode } \\
\text { Sampel }\end{array}$ & $\begin{array}{c}\mathrm{pH} \\
\left(\mathrm{H}_{2} \mathrm{O}\right)\end{array}$ & $\mathrm{C}$ & $\mathrm{N}$ & $\begin{array}{l}\mathrm{P}_{2} \mathrm{O}_{5} \\
\text { bray }\end{array}$ & $\begin{array}{r}\text { Ca- } \\
\text { dd } \\
\text { Ppm }\end{array}$ & $\begin{array}{c}\mathrm{Mg}- \\
\mathrm{dd}\end{array}$ & $\begin{array}{c}\mathrm{Na}- \\
\mathrm{dd}\end{array}$ & & $\begin{array}{r}\text { Al- } \\
\text { dd } \\
100 g_{-}\end{array}$ & KTK \\
\hline \multicolumn{7}{|c|}{ LK } & \multicolumn{4}{|c|}{ _me $/ 100 g_{-}$} \\
\hline $0-20$ & $4.47^{11}$ & $4.35^{14}$ & $0.55^{14}$ & $8.62^{11}$ & $0.2^{11}$ & $0.1^{11}$ & $0.77^{14}$ & $0.76^{14}$ & 0)1 & $13.83^{12}$ \\
\hline $20-40$ & $4.4^{11}$ & $3.25^{)^{4}}$ & $0.51^{14}$ & $15.81^{12}$ & $0.1^{11}$ & $0.1^{11}$ & $0.73^{4}$ & $0.58^{13}$ & $1.18^{11}$ & $11.95^{22}$ \\
\hline $40-60$ & $4.39^{11}$ & $3.82^{4}$ & $0.56^{4}$ & $15.09^{12}$ & $0.42^{11}$ & $0.11^{) 1}$ & $0.47^{13}$ & $0.51^{13}$ & $0.26^{1}$ & $13.62^{12}$ \\
\hline $60-80$ & $4.77^{11}$ & $3.67^{14}$ & $0.4^{13}$ & $11.81^{12}$ & $0.21^{11}$ & $0.21^{11}$ & $0.51^{13}$ & $0.4^{13}$ & $0.82^{11}$ & $19.03^{33}$ \\
\hline $80-100$ & $4.29^{11}$ & $3.97^{14}$ & $0.47^{13}$ & $5.93^{11}$ & $0.11^{11}$ & $0.11^{) 1}$ & $0.48^{13}$ & $0.48^{13}$ & o)1 & $17.8^{13}$ \\
\hline $100-120$ & $4.36^{1}$ & $3.45^{4}$ & $0.4^{13}$ & $15.21^{) 2}$ & $0.11^{11}$ & $0.11^{11}$ & $0.56^{13}$ & $0.56^{13}$ & $1.9^{11}$ & $20^{13}$ \\
\hline \multicolumn{11}{|c|}{ LA } \\
\hline $0-20$ & $4.9^{11}$ & $5.38^{15}$ & $0.58^{14}$ & $14.74^{12}$ & $1.35^{1 \mathrm{~T}}$ & $0.1^{11}$ & $0.91^{14}$ & $0.85^{14}$ & $0.36^{11}$ & $20.68^{33}$ \\
\hline $20-40$ & $4.48^{11}$ & $3.95^{)^{4}}$ & $0.54^{14}$ & $11.58^{12}$ & $0.1^{11}$ & $0.2^{1}$ & $0.68^{13}$ & $0.52^{13}$ & $0.91^{11}$ & $23.31^{13}$ \\
\hline $40-60$ & $4.54^{11}$ & $3.33^{14}$ & $0.59^{14}$ & $14.67^{2}$ & $0.21^{11}$ & $0.21^{11}$ & $1.09^{5}$ & $1.28^{5}$ & $2.57^{11}$ & $35.36^{4}$ \\
\hline $60-80$ & $4.58^{11}$ & $3.31^{14}$ & $0.37^{13}$ & $5.84^{11}$ & $0.21^{11}$ & $0.21^{) 1}$ & $0.65^{13}$ & $0.51^{13}$ & $3.66^{1}$ & $20.5^{3}$ \\
\hline $80-100$ & $4.53^{11}$ & $3.54^{4}$ & $0.51^{14}$ & $5.74^{11}$ & $0.52^{11}$ & $0.52^{12}$ & $0.46^{13}$ & $0.47^{13}$ & $2.46^{1}$ & $23.38^{13}$ \\
\hline $100-120$ & $4.54^{11}$ & $3.64^{14}$ & $0.46^{13}$ & $8.85^{11}$ & $0.11^{11}$ & $0.11^{11}$ & $0.51^{13}$ & $0.54^{13}$ & $1.4^{11}$ & $18.59^{33}$ \\
\hline \multicolumn{11}{|c|}{ DF } \\
\hline $0-20$ & $6.59^{13}$ & $5.05^{15}$ & $0.49^{13}$ & $20.75^{33}$ & $1.33^{11}$ & $0.21^{1 /}$ & $2.56^{15}$ & $0.42^{13}$ & $0^{11}$ & $29.85^{14}$ \\
\hline $20-40$ & $5.01^{) 1}$ & $3.73^{14}$ & $0.64^{13}$ & $18.73^{33}$ & $0.93^{11}$ & $0.1^{11}$ & $1.91^{55}$ & $2.18^{15}$ & $0^{31}$ & $17.45^{13}$ \\
\hline $40-60$ & $4.5^{51}$ & $3.79^{14}$ & $0.47^{13}$ & $21.09^{13}$ & $0.73^{11}$ & $0.42^{12}$ & $1.74^{5}$ & $2.09^{5}$ & $2.24^{11}$ & $22.53^{13}$ \\
\hline $60-80$ & $4.87^{11}$ & $3.62^{14}$ & $0.42^{13}$ & $11.85^{12}$ & $1.05^{1}$ & $0.84^{12}$ & $2.29^{5}$ & $2.17^{55}$ & $0.16^{1}$ & $41.76^{5}$ \\
\hline $80-100$ & $4.82^{11}$ & $3.78^{14}$ & $0.4^{13}$ & $11.88^{12}$ & $0.52^{11}$ & $1.26^{13}$ & $2.06^{5}$ & $0.56^{13}$ & $0^{1}$ & $21.12^{13}$ \\
\hline $100-120$ & $4.53^{11}$ & $3.84^{14}$ & $0.56^{4}$ & $8.82^{11}$ & $0.52^{11}$ & $0.1^{11}$ & $1.1^{15}$ & $1.05^{55}$ & $1.75^{11}$ & $18.35^{33}$ \\
\hline
\end{tabular}

Sumber : Kantor besar ASE (2011); Hasil analisa tanah di Lab. PPLH Lembaga Penelitian Universitas Lambung Mangkurat, September 2010

Keterangan : ${ }^{11}$ sangat rendah; ${ }^{12}$ rendah; ${ }^{13}$ sedang; ${ }^{44}$ tinggi; ${ }^{15}$ sangat tinggi (Berdasarkan kriteria sifat-sifat kimia tanah) (Hardjowigeno \& Widiatmaka, 2001) 
Kapasitas tukar kation (KTK). Kapasitas tukar kation (KTK) merupakan sifat kimia yang berhubungan erat dengan kesuburan tanah. Tanah dengan KTK tinggi mampu menyerap dan menyediakan unsur hara lebih baik. Tanah dengan KTK tinggi didominasi oleh kation-kation basa $(\mathrm{Ca}, \mathrm{Mg}, \mathrm{Na}, \mathrm{K})$ dapat meningkatkan kesuburan tanah, tetapi jika didominasi oleh kation asam ( $\mathrm{Al}$, dan $\mathrm{H})$ kesuburan tanah dapat berkurang (Hardjowigeno, 2003). Aplikasi limbah cair berperan dalam memperbaiki KTK tanah. Hal ini terlihat dari nilai KTK tanah di lahan aplikasi dan dalam flat bed relatif lebih baik dibandingkan di lahan kontrol (Tabel 8).

Logam-logam berat. Logam berat adalah logam yang mempunyai berat jenis $5 \mathrm{~g} / \mathrm{cm}^{3}$. Tembaga $(\mathrm{Cu})$ dan seng $(\mathrm{Zn})$ merupakan unsur mikro yang dibutuhkan tanaman. Tembaga (dalam bentuk kation $\mathrm{Cu}^{2+}$ ) bagi tanaman berperan dalam penyusunan enzim dan pembentukan klorofil, Seng (dalam bentuk kation $\mathrm{Zn}^{2+}$ ) berperan dalam pembentukan hormon pertumbuhan dan katalis dalam pembentukan protein (Hardjowigeno, 2003).

Pengambilan sampel tanah dilakukan untuk menganalisa beberapa jenis logam berat yang terdapat dalam tanah yaitu $\mathrm{Cu}, \mathrm{Pb}, \mathrm{Cd}$, dan $\mathrm{Zn}$. Kandungan logam berat $(\mathrm{Cu}, \mathrm{Pb}, \mathrm{Cd}$, dan $\mathrm{Zn})$ pada lahan kontrol terlihat lebih tinggi dibandingkan pada lahan aplikasi dan dalam flat bed untuk setiap kedalaman (Tabel 9). Hal ini disebabkan karena di lahan aplikasi dan dalam flat bed terjadi ikatan kompleks organik yang membentuk khelat, yaitu ikatan antara kation logam dengan bahan organik dalam struktur cincin (Hardjowigeno, 2003). Ikatan ini menyebabkan kation-kation logam tersebut terlindungi oleh bahan organik dan dalam reaksi kimia tidak berfungsi lagi sebagai kation, sehingga ketersediaannya pada lahan aplikasi dan dalam flat bed menjadi lebih rendah dibandingkan dengan di lahan kontrol.

Tabel 9. Kandungan logam berat pada berbagai kedalaman di lahan kontrol (LK), lahan aplikasi (LA), dan dalam flat bed (DF)

\begin{tabular}{llllllll}
\hline \multirow{2}{*}{$\begin{array}{l}\text { Logam } \\
\text { Berat }\end{array}$} & Lokasi & \multicolumn{7}{c}{ Kedalaman $(\mathrm{cm})$} \\
\cline { 3 - 7 } $\mathrm{Cu}(\mathrm{mg} / \mathrm{g})$ & Sampel & $0-20$ & $20-40$ & $40-60$ & $60-80$ & $80-100$ & $100-120$ \\
& LK & 3.956 & 3.936 & 3.769 & 3.921 & 3.911 & 2.147 \\
& LA & 0.2003 & 0.0356 & 0.0393 & 0.0324 & 0.2716 & 0.0848 \\
& DF & 0.0159 & 0.0216 & 0.0153 & 0.0222 & 0.0356 & 0.0358 \\
\hline \multirow{3}{*}{$\mathrm{Pb}(\mathrm{mg} / \mathrm{g})$} & LK & 0.0741 & 0.0725 & 0.0183 & 0.0696 & 0.0538 & 0.0349 \\
& LA & 0.0391 & 0.0025 & 0.0017 & 0.0018 & 0.0048 & 0.0064 \\
& DF & 0.0055 & 0.0012 & 0.0029 & 0.0052 & 0.0052 & 0.0053 \\
\hline \multirow{3}{*}{$\mathrm{Cd}(\mathrm{mg} / \mathrm{g})$} & LK & 0.0326 & 0.0326 & 0.0081 & 0.0272 & 0.0195 & 0.0012 \\
& LA & 0.0015 & 0.001 & 0.0016 & 0.0019 & 0.0021 & 0.001 \\
& DF & 0.0029 & 0.0003 & 0.0017 & 0.0012 & 0.021 & 0.0039 \\
\hline \multirow{3}{*}{$\mathrm{Zn}(\mathrm{mg} / \mathrm{g})$} & LK & 0.8233 & 0.8185 & 0.8009 & 0.8203 & 0.8177 & 0.7549 \\
& LA & 0.6033 & 0.2479 & 0.1781 & 0.1718 & 0.6003 & 0.3367 \\
& DF & 0.08 & 0.119 & 0.0687 & 0.0953 & 0.1504 & 0.1429 \\
\hline
\end{tabular}

Sumber : Kantor besar ASE (2011); Hasil analisa tanah di Lab. PPLH Lembaga Penelitian Universitas Lambung Mangkurat, Sepetember 2010

\section{Dampak Aplikasi Limbah Cair terhadap Kualitas Air}

Pengamatan dampak aplikasi limbah cair terhadap kualitas air dilakukan dengan mengambil sampel air pada beberapa titik yaitu sumur pantau I dan II pada lahan aplikasi, sumur penduduk (perumahan karyawan divisi III ASE) dan air sungai (hulu dan hilir) kemudian membandingkan dengan baku mutu standar yang ditetapkan pemerintah (Peraturan Pemerintah Republik Indonesia No. 82 tahun 2001 tentang pengelolaan kualitas air dan pengendalian pencemaran air).

\section{Kualitas Air Tanah Dangkal}

Penilaian kualitas air tanah dangkal dilakukan pada sumur pantau I (blok B21), sumur pantau II (blok B22), dan sumur penduduk (perumahan karyawan divisi III ASE). Berdasarkan baku mutu air kelas satu PP No. 82 tahun 2001, kandungan BOD dan COD pada sumur pantau I dan II dan sumur penduduk berada di atas kadar maksimum yang ditetapkan. Artinya berdasarkan baku mutu air kelas IV, air sumur penduduk tidak cocok digunakan untuk air minum. Hal ini disebabkan karena adanya rembesan limbah cair yang diaplikasikan atau limpahan air limbah dari dalam flat bed pada saat 
terjadi hujan. Karakteristik kimia air tanah dangkal (SPI, SPII, dan sumur penduduk) disajikan pada Tabel 10.

Tabel 10. Karakteristik kimia air tanah pada sumur pantau (SP I dan SP II) di lahan aplikasi dan sumur penduduk

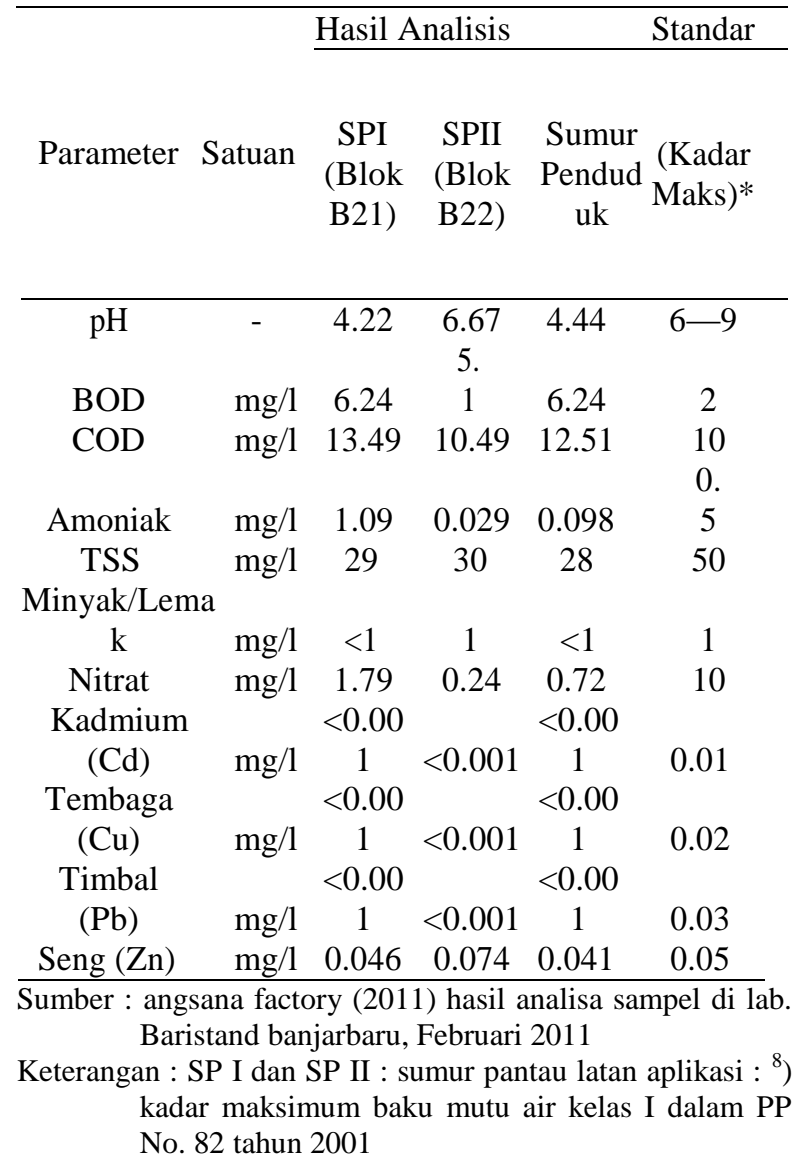

2. Kualitas Air Permukaan (Air Sungai Hulu dan Hilir)

Penilaian kualitas air permukaan dilakukan dengan melakukan analisa terhadap air sungai sebamban (hulu dan hilir). Berdasarkan hasil analisa, kualitas air permukaan baik pada hulu maupun hilir sungai menunjukkan kualitas yang relatif sama serta tidak melebihi baku mutu (kadar maksimum) yang dipersyaratkan (Tabel 13). Artinya aplikasi limbah cair tidak berdampak negatif bagi air permukaan (air sungai) jika peruntukannya sesuai dengan golongan air kelas IV PP No. 82 tahun 2001. Hal ini menunjukkan bahwa pengawasan terhadap kemungkinan limpahan atau rembesan air limbah mengalir ke sungai sudah dilakukan dengan baik.

\section{KESIMPULAN}

Hasil samping (by product) dari pengolahan TBS di PKS berupa janjangan kosong dan POME bermanfaat sebagai pupuk organik (sebagai bahan pembenah dan penyumbang unsur hara tanah di perkebunan kelapa sawit). Aplikasi JJK berpengaruh positif terhadap ketersediaan unsur hara Kalium dalam daun tetapi belum meningkatkan produtivitas tanaman secara konsisten. Secara khusus aplikasi JJK di ASE belum dilakukan sebagai substitusi bagi penggunaan pupuk anorganik, masih sebatas sebagai suplemen saja.

Pengolahan limbah cair pada stasiun IPAL di ASE menggunakan sistem kolam karena dinilai masih efektif dan ekonomis. Aplikasi limbah cair berpengaruh positif terhadap kesuburan tanah terlihat dari perbaikan tekstur tanah, perbaikan bobot per volume dan permeabilitas tanah, memperbaiki $\mathrm{pH}$ tanah, meningkatkan KTK tanah dan tidak berdampak negatif terhadap kualitas air permukaan. Aplikasi limbah cair dapat meningkatkan produtivitas tanaman terutama melalui peningkatan perolehan jumlah JJG/ha/tahun tetapi belum menunjukkan dampak yang positif terhadap status hara dalam daun.

\section{DAFTAR PUSTAKA}

Departemen Riset, Minamas Plantation. 2006. Laporan Akhir Survei Tanah Semi Detil di Kebun Angsana PT Ladangrumpun Suburabadi. Departemen Riset, Minamas Plantation. Teluk Siak. 23 hal.

Hardjowigeno, S. 2003. Ilmu Tanah. Jakarta (ID): Akademika Presindo. 286 hal.

Hardjowigeno, S., Widiatmaka. 2001. Kesesuaian Lahan dan Perencanaan Tataguna Tanah. Jurusan Tanah Fakultas Pertanian. Institut Pertanian Bogor. 381 hal.

Lembaga Penelitian Pusat Penelitian Lingkungan Hidup, Universitas Lambung Mangkurat. 2010. Hasil Analisa Tanah. Lembaga Penelitian Pusat Penelitian Lingkungan Hidup, Universitas Lambung Mangkurat. Banjarbaru. 2 hal.

Minamas Research Centre, Minamas Plantation. 2009. Hasil Analisa Daun. Minamas Research Centre, Minamas Plantation. Teluk Siak. 5 hal.

Pahan, I. 2007. Panduan Lengkap Kelapa Sawit. 3. Jakarta (ID): Penebar Swadaya. 411 hal. 
Pusat Data dan Informasi Pertanian Kementerian Pertanian. 2010. Outlook Komoditas Pertanian - Perkebunan. [Internet] [diunduh 5 Jan 2011]. Tersedia pada : http://www.deptan.go.id/pusdatin/admin/P UB/Outlook/o utlook_komoditas_bun.pdf.
Sugiharto. 1987. Dasar-dasar Pengelolaan Air Limbah. Jakarta (ID): Penerbit Universitas Indonesia (UI-Press). 190 hal.

Walpole, R. E. 1993. Pengantar Statistika. Jakarta (ID): Penerbit PT Gramedia Pustaka Utama. $\quad 515$ hal. 